\title{
Burn wound angiogenesis is increased by exogenously administered recombinant leptin in rats ${ }^{1}$
}

\author{
A administração exógena de leptina recombinante induz à angiogênese em queimaduras \\ cutâneas provocadas em ratos
}

\author{
Ioannis Liapakis ${ }^{\mathrm{I}}$, Stavros Anagnostoulis ${ }^{\mathrm{II}}$, Anastasios Karayiannakis ${ }^{\mathrm{II}}$, Dimitris Korkolis ${ }^{\mathrm{IV}}$, Maria Lambropoulou ${ }^{\mathrm{III}}$, \\ Alan Matarasso ${ }^{\mathrm{V}}$, Constantinos Simopoulos ${ }^{\mathrm{II}}$
}

${ }^{\mathrm{I}} \mathrm{MD}$, PhD, Department of Plastic and Reconstructive Surgery, Hellenic Anticancer Institute, "Saint Savvas" Hospital, Athens, Greece.

II MD, PhD, 2nd Department of Surgery, Medical School, Democritus University of Thrace, Alexandroupolis, Greece.

III.MD, PhD Department of Histology-Embryology, Medical School, Democritus University of Thrace, Alexandroupolis, Greece.

Iv $\mathrm{MD}, \mathrm{PhD}, 1^{\text {st }}$ Department of Surgical Oncology, Hellenic Anticancer Institute, "Saint Savvas" Hospital, Athens, Greece.

${ }^{v}$ MD, Division of Plastic Surgery, Albert Einstein College of Medicine/Montefiore Medical Center, New York City, NY.

\begin{abstract}
Background: Leptin is a potent direct angiogenic factor that stimulates endothelial cell migration and activation in vitro and angiogenesis in vivo. In addition, leptin has been discussed to play an important role in angiogenesis, as it promotes the formation of new blood vessels. Purpose: The effect of exogenously administered leptin on the healing process of a full tissue burn wound model. Methods: Sixty-three Sprague-Dawley male rats were used. Full tissue burn wound was created by electrocautery. The width of the pin was $0.3 \mathrm{~cm}$; its length was $2 \mathrm{~cm}$ and was used at the "cut" modulation. Rats were divided into seven groups of nine animals each. Burn wounds were injected with murine recombinant leptin and the rats were sacrificed 3, 7 and 9 days after surgery. Every group had obtained three animals for the three different days of sacrifice. Three different leptin doses of $250 \mathrm{pg} / \mathrm{ml}, 500 \mathrm{pg} / \mathrm{ml}$ and $1000 \mathrm{pg} / \mathrm{ml}$ were used in different animal groups (A, B and C). For every one of the three leptin doses used, another animal group was evaluated by using the combined injection of leptin and antileptin (A1, B1, and C1), in order to study the inhibitory effect to the leptin factor. Nine rats were served as controls. These were injected with $0.3 \mathrm{ml}$ water for injection solution and sacrificed at the same time intervals. After sacrifice of the animals, the skin was grossly determined by its appearance, colour and texture. Full thickness burn wounds were dissected for histological examination. A qualitative analysis of angiogenesis in the burn wound was conducted following a standard hematoxylin and eosin stain. The wound tissue samples from each experimental group underwent immunohistochemical evaluation of microvessel density by endothelial cell staining with mouse anti-rat CD 34 monoclonal antibody. Results: The most impressive growth of new blood vessels appeared seven and nine days after treatment with the highest leptin doses. There were no significant differences in microvessel density between the seventh and the ninth postoperative day among different groups treated with leptin. All wounds from the control group, as well as those from animal groups treated with the combined injection of leptin and antileptin did not develop any new vessels. Conclusion: Exogenous administration of recombinant leptin increases early tissue angiogenesis in the burn wound level of an experimental animal model.
\end{abstract}

Key words: Leptin. Skin. Wound Healing. Angiogenesis Inducing Agents.

RESUMO

Introdução: A leptina é um potente fator angiogênico que estimula a migração e a ativação de células endoteliais in vitro e a angiogênese in vivo. Além disso, a leptina tem sido considerada importante na angiogênese pois ela promove a formação de novos vasos sanguíneos. Objetivo: Investigar o efeito da leptina administrada por via exógena no processo de cicatrização em um modelo experimental de queimadura. Métodos: Foram utilizados sessenta e três ratos SpragueDawley, machos. A lesão de espessura total da queimadura foi realizada por eletrocautério. O dano tecidual foi de $0.3 \mathrm{~cm}$ numa extensão de $2 \mathrm{~cm}$ tendo sido empregada o módulo de "corte"do eletrocautéio. Os ratos foram distribuídos em sete grupos de nove animais. As lesões por queimadura receberam leptina recombinante. Os animais foram sacrificados $3,7 \mathrm{e}$ 9 dias após o ato operatório. Obteve-se três animais de cada grupo nos três períodos estipulados. Três diferentes dosagens de leptina: $250 \mathrm{pg} / \mathrm{ml}, 500 \mathrm{pg} / \mathrm{ml} \mathrm{e} 1000 \mathrm{pg} / \mathrm{ml}$ foram aplicados nos três diferentes grupos (A, B e C). Para cada uma das três dosagens de leptina, outro grupo de animais foi avaliado pelo uso de injeção combinada de leptina e antileptina (A1, B1 e C1) no sentido de investigar o efeito inibitório do fator leptina. Nove ratos serviram de controles. Estes foram submetidos à injeção de $0.3 \mathrm{ml}$ de água e sacrificados nos mesmos intervalos de tempo. Após o sacrifício dos animais, o tegumento foi avaliado por sua aparência, cor e textura. Fragmentos das feridas queimadas foram ressecadas para exame histológico. A análise qualitativa de angiogênese, na ferida queimada, seguia o padrão da coloração de hematoxilina e eosina. Cada fragmento de tecido, de cada grupo experimental, foi submetido à avaliação imunohistoquímica da densidade dos microvasos pela coloração da célula endotelial por anti-rato CD 34 anticorpo monoclonal. Resultados: O desenvolvimento de novos vasos sanguíneos foi mais significativo após sete e nove dias do tratamento com as altas doses de leptin. Não houve diferenças significativas de densidade de microvasos entre o sétimo e o nono dia pós-operatório entre os diferentes grupos tratados com leptina. Todas as feridas do grupo controle assim como dos outros grupos de animais, com a injeção combinada de leptina e antileptina, não desenvolveram novos vasos. Conclusão: A administração exógena de leptina recombinante aumenta a angiogênese tecidual em queimaduras em modelo experimental.

Descritores: Leptina. Pele. Cicatrização de Feridas. Agentes Indutores da Angiogênese.

1. Research performed at the Department of Experimental Surgery of the University of Thrace Medical School. 


\section{Introduction}

During the wound healing processes, an abundant blood supply is necessary to meet the enormous local demands of debridement, fibroblast proliferation, extracellular matrix synthesis, and epithelialization ${ }^{1,2,3}$. Impairment of blood supply may be a contributing factor in delayed healing, or nonhealing, in chronic wounds such as diabetic foot ulcers, pressure ulcers, and wounds caused by chronic and acute arterial occlusion ${ }^{4,5}$. Recent advances in the understanding of neovascularisation have made angiogenesis a prime target for therapeutic manipulation in wound healing. Efforts have been made to induce or stimulate new blood vessel formation in order to reduce the unfavourable tissue effects caused by local ischaemia or to enhance tissue repair ${ }^{6,7,8}$. Growth factors, which are now known to participate in cell division, migration, differentiation, and enzyme production, are also important regulators of wound angiogenesis ${ }^{9,10}$. Consequently, intense interest is now focused on the pharmacological application of angiogenic growth factors in the compromised wound $^{8,11,12,13,14,15}$.

Leptin is a potent direct angiogenic factor that stimulates endothelial cell migration and activation in vitro, and angiogenesis in vivo ${ }^{16-22}$. The observation that leptin mediates angiogenic and mitogenic effects in vitro further implicates an important role for leptin as a mitogenic factor during tissue regeneration in vivo. In addition, leptin seems to play an important role in angiogenesis, as it promotes new blood vessels formation ${ }^{20,23}$.

In this study, the effect of leptin on a burn wound healing model in mice was evaluated. Angiogenesis of healing wounds was examined after administration of exogenous leptin. It was measured in different stages of postoperative tissue re-epithelialization and remodelling, by using both conventional staining and immunohistochemistry.

\section{Methods}

Sixty-three male rats were used for the study, each weighing between $240-500 \mathrm{~g}$. The animals were housed in individual cages. They were obtained from the "Department of Physiology" (University of Thrace, Alexandroupolis, Greece) and maintained under a 12-hour-light/12-hour-dark cycle at $22^{\circ} \mathrm{C}$ until they reached 30 weeks of age. At this time they were caged individually, allowed food and water ad libitum and monitored for body weight. This project was conducted in the "Department of Experimental Surgery", Medical School, University of Thrace and was supervised by the University's veterinarian. The "Veterinary Administration Medical Center", Alexandroupolis, Greece and the University Ethical Committee, approved the study protocol.

\section{Preparation of wound tissues}

After induction of general anaesthesia with ether and subcutaneous administration of ketamine hydrochloride $(87 \mathrm{mg} / \mathrm{Kg})$ and xylazine hydrochloride $(13 \mathrm{mg} /$ $\mathrm{Kg}$ ), the dorsal regions of the rats were shaved and depilated. The animals were placed in a prone position. A full tissue burn wound was created by electrocautery (Ellman Surgitron FFPF EMC Electrosurgical). The width of the pin was 0.3 $\mathrm{cm}$; its length was $2 \mathrm{~cm}$ and was used at the "cut" modulation for 3 seconds.

All operative procedures were performed under aseptic conditions and after operation every rat was kept in an individual cage. All the rats were determined for body weight, both before and after the end of the experiment.

The rats were divided into seven groups of nine animals each.

Burn wounds were injected with murine recombinant leptin (Cytolab Ltd. / Pepro Tech Asia, Rehovot, Israel) in $0.3 \mathrm{~mL}$ PBS per injection and the mice were sacrificed 3, 7 and 9 days after. Every group had obtained three animals. Three different doses of murine recombinant leptin had been used: $250 \mathrm{pg} / \mathrm{ml}$ (group A), 500 $\mathrm{pg} / \mathrm{ml}$ (group B) and $1000 \mathrm{pg} / \mathrm{ml}$ (group C) (in $0.3 \mathrm{~mL} \mathrm{PBS}$ per injection). For every of the three doses of the leptin used another group had obtained with injection of the leptin with antileptin (group A1: $250 \mathrm{pg} / \mathrm{ml}$ leptin with $375 \mathrm{pg} / \mathrm{ml}$ antileptin, group B1: $500 \mathrm{pg} / \mathrm{ml}$ leptin with $750 \mathrm{pg} / \mathrm{ml}$ antileptin, group C1: $1000 \mathrm{pg} / \mathrm{ml}$ leptin with $1500 \mathrm{pg} / \mathrm{ml}$ antileptin) in order to study the inhibition of the leptin factor (Table 1).

TABLE 1 - Groups of mice with different doses of leptin, antileptin, WFI treated for 3, 7 and 9 days

\begin{tabular}{llcc}
\hline & INJECTION & $\begin{array}{c}\text { NUMBER } \\
\text { OF ANIMALS }\end{array}$ & $\begin{array}{c}\text { DAYS OF } \\
\text { TREATMENT }\end{array}$ \\
A & 250pgr/ml / 0,3ml leptin & $\mathbf{1 , 2 , 3}$ & $\mathbf{3 , 7 , 9}$ \\
B & $\mathbf{5 0 0 p g r / m l / 0 , 3 m l ~ l e p t i n ~}$ & $\mathbf{1 , 2 , 3}$ & $\mathbf{3 , 7 , 9}$ \\
C & $\mathbf{1 0 0 0 p g r / m l / 0 , 3 m l ~ l e p t i n ~}$ & $\mathbf{1 , 2 , 3}$ & $\mathbf{3 , 7 , 9}$ \\
A1 & $\mathbf{2 5 0 p g r / m l / 0 , 3 m l ~ l e p t i n ~ + 3 7 5 p g r / a n t i l e p t i n ~}$ & $\mathbf{1 , 2 , 3}$ & $\mathbf{3 , 7 , 9}$ \\
B1 & $\mathbf{5 0 0 p g r / m l / 0 , 3 m l ~ l e p t i n ~ + 7 5 0 p g r / a n t i l e p t i n ~}$ & $\mathbf{1 , 2 , 3}$ & $\mathbf{3 , 7 , 9}$ \\
C1 & 1000pgr/ml/0,3ml leptin +1500pgr/antileptin & $\mathbf{1 , 2 , 3}$ & $\mathbf{3 , 7 , 9}$ \\
Control & W.F.I (Control) 0,3ml & $\mathbf{1 , 2 , 3}$ & $\mathbf{3 , 7 , 9}$ \\
\hline
\end{tabular}


Nine rats were served as controls, were injected with $0.3 \mathrm{ml}$ water for injection (WFI) solution and sacrificed 3, 7 and 9 days after (Table 1).

\section{Histological and immunohistochemical} evaluation

Burn wounds in full thickness were dissected for histological examination. The specimens were fixed in $10 \%$ formalin, stored at $4^{\circ} \mathrm{C}$ and sectioned longitudinally at $2 \mu \mathrm{m}$ thickness. A qualitative analysis of angiogenesis in the wound was performed following a standard hematoxylin and eosin (HE) stain.

Further analysis was performed by immunohistological assay. Surface endothelial cells were detected by a monoclonal anti-mouse anti-rat CD 34 antibody (Innovex Biosciences, Ca, USA; dilution, 1:40). The slides were incubated in microwave oven for $15 \mathrm{~min}$. The immunohistological stain was performed in $2 \mu \mathrm{m}$ of paraffin sections and the specimens were embedded in super frost plus Tissue Tek. The sections were cleaned and they were put in the microwave oven in Trilogy liquid. After cleaning with $\left(\mathrm{H}_{2} \mathrm{O}_{2}\right) 3 \%$ and sterilize water, the sections were incubated with A-kit for 25 min (special anti-serum). They were put to react with diaminobenzidine (DAB) for $15 \mathrm{~min}$ in order to retrace the positive immunoreaction and then washed with PBS for 5 min. Dehydration process conducted with scale of alcohol and lucidity-coverage of the sections.

The incubation was performed in high temperature in order to increase the sensitivity of the $\operatorname{stain}^{24}$ This method improves the immunohistological expression, decreases the non-special stain and allows higher dilution of the initial antibodies ${ }^{25,26,27}$. The control group used consisted of histological sections with known positiveness in the antibodies used.

Optical micrographs under a Nikon Eclipse E 200 microscope (X400), were taken.

\section{Statistical analysis}

Statistical analysis was performed using the ANOVA test. A two-tailed unpaired Student's t-test or an analysis of variance was used to analyze differences between groups. A p value less than 0.05 was considered statistically significant.

\section{Results}

From gross examination, the surface of the burn wounds healed without any complications in both experimental and control groups at 3, 7 and 9 days, postoperatively.

Wound tissue samples from each experimental group were evaluated for the level of microvessel density (MVD). All endothelial cells were stained with anti-rat CD 34 antibody. Microvessels were represented by brown capillaries (Figure 1).

\section{A}

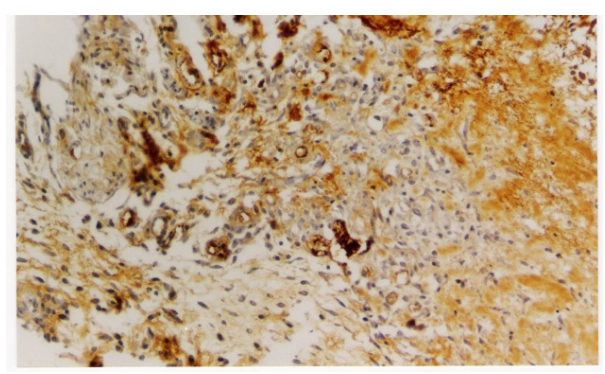

$\mathbf{B}$

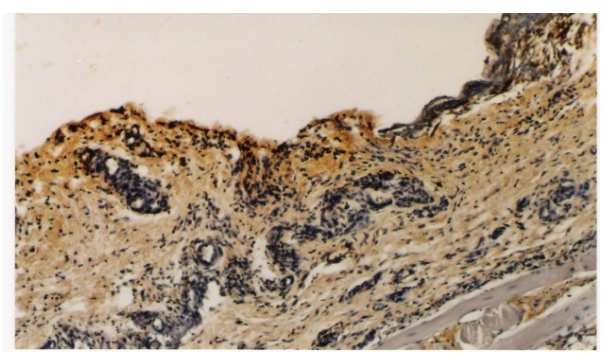

C

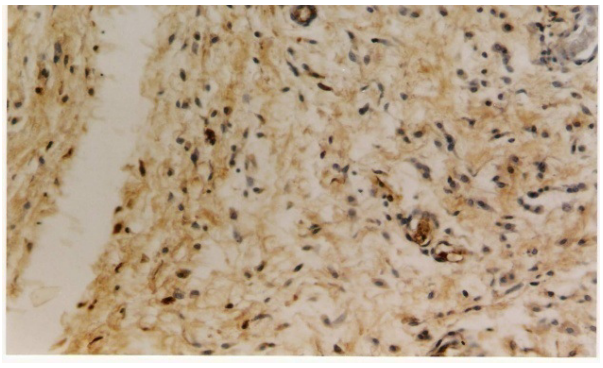

FIGURE 1 - The histological anti-rat CD 34 staining of wound tissue samples from: (A) burn wound with leptin $1000 \mathrm{pg} / \mathrm{ml} 3$ days postoperatively; (B) burn wound with $0.3 \mathrm{ml}$ WFI 3 days postoperatively; (C) $250 \mathrm{pgr} / \mathrm{ml}+375 \mathrm{pgr} /$ antileptin injection, 3 days postoperatively. Endothelial cells stained with the antibody were represented by brown colour

It was found that $\mathrm{C}$ leptin $1000 \mathrm{pg} / \mathrm{ml}$ outperforms the other three leptin categories and had the largest numbers of vessels in comparison to the other six categories.

The variable with the second best performance was the B group of leptin with $500 \mathrm{pg} / \mathrm{ml}$.

The differential comparison between various groups of leptin proved to be statistically significant. Among the three different doses of exogenously administered leptin, the most impressive new vessel formation was documented seven days after treatment. There was growth of inflammatory granulus tissue and angiogenesis foci around the lesion, hyperplasia of squamous epithelium, increase, fattening and irregular disposition of the collagen fibers.

The semi-quantitative assessment of MVD (mean \pm SD) showed a statistically significant difference between wound repair, with different doses of leptin in different postoperative days. However, there were no significant differences in MVD among the leptin treated groups at 7 and 9 days, postoperatively. This comparison is shown in Figure 2. 


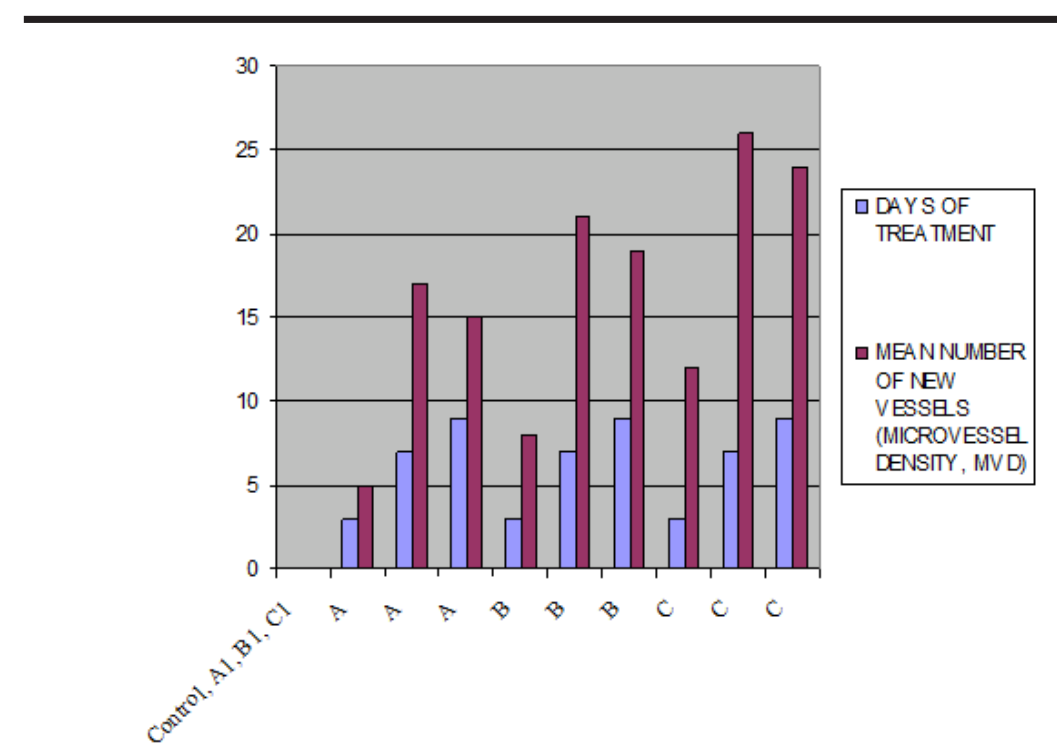

FIGURE 2 - Comparison of MVD between each experimental animal group

TABLE 2 - Mean numbers of new vessels in different groups of mice treated with leptin, leptin + antileptin or WFI

\begin{tabular}{|c|c|c|}
\hline $\begin{array}{l}\text { INJECTION } \\
\text { (MICROVESSEL DENSITY, MVD) }\end{array}$ & DAYS OF SACRIFICE & $\begin{array}{l}\text { MEAN NUMBER } \\
\text { OF NEW VESSELS }\end{array}$ \\
\hline
\end{tabular}

\begin{tabular}{lll}
\hline Control, A1, B1, C1 & $3,7,9$ & 2 \\
A & 3 & 5 \\
A & 7 & 17 \\
A & 9 & 15 \\
B & 3 & 8 \\
B & 7 & 21 \\
B & 9 & 19 \\
C & 3 & 12 \\
C & 7 & 26 \\
C & 9 & 24 \\
\hline
\end{tabular}

A: injection with $250 \mathrm{pg} / \mathrm{ml} / 0,3 \mathrm{ml}$ leptin, B: injection with $500 \mathrm{pgr} / \mathrm{ml} / 0,3 \mathrm{ml}$ leptin, C: injection with $1000 \mathrm{pgr} / \mathrm{ml} / 0,3 \mathrm{ml}$ leptin, A1: injection with $250 \mathrm{pgr} / \mathrm{ml} / 0,3 \mathrm{ml}$ leptin $+350 \mathrm{pgr} /$ antileptin, B1: injection with $500 \mathrm{pgr} / \mathrm{ml} / 0,3 \mathrm{ml}$ leptin $+750 \mathrm{pgr} /$ antileptin, C1: injection with $1000 \mathrm{pgr} / \mathrm{ml} / 0,3 \mathrm{ml}$ leptin $+1500 \mathrm{pgr} /$ antileptin, Control: injection with WFI $0,3 \mathrm{ml}$

All nine wounds from the control group and the twenty seven ones injected with the combination of leptin and antileptin did not disclose any formation of new blood vessels. There was growth of inflammatory granulus tissue, with inflammatory cells of mixed type, fibrinoblastocells and fibrins of collagen instead (Table 2). Most of the wounds in three days for the 3 different doses of the leptin had growth of inflammatory granulus tissue, fibrinoblastocells and fibrins of collagen and appear formation of new vessels especially at the edges of the wound (Table 2). There was broad development of fibroblasts focused toward the center with no signs of necrosis (Table 2). Nine days after treatment, there was marked hyperplasia of squamous epithelium, increase, fattening and irregular disposition of the collagen fibers.
There was growth of fibroblasts focused toward the center with no signs of necrosis.

\section{Discussion}

Angiogenesis is a biological mechanism of new capillary formation. It involves the activation, migration, and proliferation of endothelial cells from preexisting venules. It can be influenced by factors like hypoxia, matrix components, metabolic gradients and growth factors ${ }^{1,2}$.

Growth factors driving re-epithelialization are central to the wound-healing process. Crucial roles for this process have been elucidated for KGF, EGF, and TGF-•, which have been shown to stimulate re-epithelialization in animal models or to be absent in models of impaired re- 
epithelialization In line with these observations, keratinocytes of the hyperproliferative epithelium at the wound edge and endothelial cells are known to express the KGF- or EGF-receptor, respectively ${ }^{28}$.

Repertinger et al. ${ }^{29}$ demonstrated that EGFR regulates multiple facets of cutaneous wound healing, including inflammation, wound contraction, proliferation, migration, and angiogenesis.

Galiano et al..$^{30}$ demonstrated that pharmacological VEGF therapy in diabetics enhances neovascularization with a clinically significant effect. The mechanism for this effect is through a stimulation of local angiogenesis, enhanced expression of growth factors including PDGF and FGF-2, and a systemic mobilization of bone marrow-derived stem cells. This combination of effects is likely responsible for the increased perfusion, improved peripheral neuropathy, and enhanced collateral formation. Because VEGF is uniquely able to enhance local angiogenesis and mobilize endothelial progenitors into the circulation, VEGF therapy may be exploited to promote tissue repair in a wide variety of acute and chronic injuries, particularly in conditions such as diabetes mellitus or aging.

The beneficial effect of leptin on wound repair is due to a direct mitogenic action of leptin on keratinocytes located at the wound margins ${ }^{31}$.

The angiogenic activation of endothelial cells probably plays a role in promoting and regulating other biological events, such as inflammation, fibroblast proliferation, extracellular matrix synthesis, and epithelialization in wound healing.

Leptin is an endogenous stimulator of both angiogenesis and increased vascular permeability ${ }^{18,19}$.This process is believed to be essential for neovascularisation to occur. Leptin is expressed in developing blood vessels and its receptors are found exclusively on endothelial cells ${ }^{21}$. The expression of leptin is believed to be potentiated in response to ischaemia by activated oncogenes and a variety of cytokines ${ }^{22}$. Leptin has been demonstrated to mediate angiogenic activity during the proliferative phase of wound healing ${ }^{23}$

In the present study, notable differences between the study groups were encountered. Blood flow measurements varied significantly from group to group. More importantly, there was improved re-epithelialization of burn wounds in rats and accelerated normal wound healing. Wounds that received leptin had markedly improved tissue survival particularly for the highest doses and in 7 or 9 days after treatment.

Differences between the experimental groups were also noted when the tissues were examined under the light microscope. In those animals that received leptin, the subcutaneous tissue supplying the wound contained a greater number of total blood vessels. Similar results were not noted in those animals that received either $0,3 \mathrm{ml}$ W.F.I or leptin with the blocking factor antileptin in each dose used. This may be attributed to the manipulation of the wound without the addition of beneficial gene therapy.

Immunohistochemical staining confirmed the production of the protein in the healing tissues. The amount of protein noted in each group of specimens could be quantified by the intensity of the antigen-antibody complex deposition and staining. Complex deposition was most pronounced in tissues receiving leptin. The operated specimens in the WFI - leptin/antileptin treated groups had significantly less intense staining.

These results demonstrate that burn wound treatment with recombinant leptin could accentuate the cellular response by producing increased amounts of leptin as a means of augmenting the production of nutrient blood vessels and the viability of the neovascularized tissue.

These experimental findings are in accordance with previous studies. Kino et al. ${ }^{32}$ suggested that the plasma leptin level may have some relations to plasma proinflammatory cytokines in pathophysiologic responses to critical conditions of burn injury. Cakir et al. ${ }^{33}$ demonstrated that leptin may provide a therapeutic benefit in diminishing burn-induced inflammation and associated multiple organ failure.

\section{Conclusion}

This burn wound healing animal model demonstrates that the application of exogenous leptin could improve angiogenesis in the wound tissue. It provides strong evidence of an angiomodulatory strategy that leptin may express in burns.

\section{Acknowledgements}

We would like to thank Mr Petros Ypsilantis, Associate Professor in the Department of Experimental Surgery, Veterinarian in the "Laboratory of Experimental Surgery and Surgical Research", School of Medicine, Democritus University of Thrace, Alexandroupolis, Greece, for his assistance finishing this study.

\section{References}

1. Thompson WD, Harvey JA, Kazmi MA, Stout AJ. Fibrinolysis and angiogenesis in wound healing. J Pathol. 1991;165:311-8.

2. Arnold F, West DC. Angiogenesis in wound healing. Pharmacol Ther. 1991;52:407-22.

3. Bodary PF, Westrick RJ, Wickenheiser KJ, Shen Y, Eitzman DT. Effect of leptin on arterial thrombosis following vascular injury in mice. JAMA. $2002 \mathrm{Apr}$ 3;287(13):1706-9.

4. Schafer K, Halle M, Goeschen C, Dellas C, Pynn M, Loskutoff DJ, Konstantinides S. Leptin promotes vascular remodeling and neointimal growth in mice. Arterioscler Thromb Vasc Biol. 2004 Jan;24(1):112-7.

5. Schafer K, Konstantinides S, Riedel C, Thinnes T, Muller K, Dellas C, Hasenfuss G, Loskutoff DJ. Different mechanisms of increased luminal stenosis after arterial injury in mice deficient for urokinase- or tissue-type plasminogen activator. 
Circulation. 2002 Oct 1;106(14):1847-52.

6. Konstantinides S, Schafer K, Neels JG, Dellas C, Loskutoff DJ. Inhibition of endogenous leptin protects mice from arterial and venous thrombosis. Arterioscler Thromb Vasc Biol. 2004 Nov;24(11):2196-201.

7. Bodary PF, Shen Y, Ohman M, Bahrou KL, Vargas FB, Cudney SS, Wickenheiser KJ, Myers MG Jr, Eitzman DT. Leptin regulates neointima formation after arterial injury through mechanisms independent of blood pressure and the leptin receptor/STAT3 signaling pathways involved in energy balance. Arterioscler Thromb Vasc Biol. 2007 Jan;27(1):70-6.

8. Torsney E, Mayr U, Zou Y, Thompson WD, Hu Y, $\mathrm{Xu}$ Q. Thrombosis and neointima formation in vein grafts are inhibited by locally applied aspirin through endothelial protection. Circ Res. 2004 Jun 11;94(11):1466-73.

9. Bodary PF, Gu S, Shen Y, Hasty AH, Buckler JM, Eitzman DT. Recombinant leptin promotes atherosclerosis and thrombosis in apolipoprotein E-deficient mice. Arterioscler Thromb Vasc Biol. 2005 Aug;25(8):119-22.

10. Beltowski J. Leptin and atherosclerosis. Atherosclerosis. 2006 Nov;189(1):47-60.

11. Breitbart A.S, Grande DA, Laser J, et al. Treatment of ischemic wounds using cultured dermal fibroblasts transduced retrovirally with PDGF-B and VEGF121 genes. Ann Plast Surg 2001;46:55561.

12. Imagawa K, Numata Y, Katsuura G, Sakaguchi I, Morita A, Kikuoka S, Matumoto Y, Tsuji T, Tamaki M, Sasakura K, Teraoka H, Hosoda K, Ogawa Y, Nakao K. Structure-function studies of human leptin. J Biol Chem. 1998 Dec 25;273(52):35245-9.

13. Suganami E, Takagi H, Ohashi H, Suzuma K, Suzuma I, Oh H, Watanabe D, Ojima T, Suganami T, Fujio Y, Nakao K, Ogawa Y, Yoshimura N. Leptin stimulates ischemia-induced retinal neovascularization: possible role of vascular endothelial growth factor expressed in retinal endothelial cells. Diabetes. 2004 Sep;53(9):2443-8.

14. Ueno N, Dube MG, Inui A, Kalra PS, Kalra SP. Leptin modulates orexigenic effects of ghrelin and attenuates adiponectin and insulin levels and selectively the dark-phase feeding as revealed by central leptin gene therapy. Endocrinology. 2004 Sep;145(9):4176-84.

15. Bernotiene E, Palmer G, Talabot-Ayer D, SzalayQuinodoz I, Aubert ML, Gabay C. Delayed resolution of acute inflammation during zymosan- induced arthritis in leptin-deficient mice. Arthritis Res Ther. 2004;6(3):R256-63.

16. Jequier E. Leptin signaling, adiposity, and energy balance. Ann N Y Acad Sci. 2002 Jun;967:379-88.

17. Papathanassoglou E, El-Haschimi K, Li XC, Matarese G, Strom T, Mantzoros C. Leptin receptor expression and signaling in lymphocytes: kinetics during lymphocyte activation, role in lymphocyte survival, and response to high fat diet in mice. J Immunol. 2006 Jun 15;176(12):7745-52.

18. Bouloumie A., Drexler HC, Lafontan M, Busse R. Leptin, the product of $\mathrm{Ob}$ gene, promotes angiogenesis. Circ Res. 1998;83:1059-66.

19. Santos-Alvarez J, Goberna R, Sanchez-Margalet V. Human leptin stimulates proliferation and activation of human circulating monocytes. Cell Immunol. 1999;194:6-11.

20. Tsuchiya T, Shimizu H, Horie T, Mori M. Expression of leptin receptor in lung: leptin as a growth factor. Eur J Pharmacol. 1999;365:273-9.

21. Tanabe K, Okuya S, Tanizawa Y, Matsutani A, Oka Y. Leptin induces proliferation of pancreatic beta cell line MIN6 through activation of mitogenactivated protein kinase. Biochem Biophys Res Commun. 1997;241:765-8.

22. Islam MS, Morton NM, Hansson A, Emilsson V. Rat insulinoma-derived pancreatic beta-cells express a f1997unctional leptin receptor that mediates a proliferative response. Biochem Biophys Res Commun. 1997;238:851-5.

23. Sierra-Honigmann MR et al. Biological action of leptin as an angiogenic factor. Science. 1998;281:1683-6.

24. Flenghi L, Ye BH, Fizzotti M, Bigerna B, Cattoretti G, Venturi S, Pacini R, Pileri S, Lo Coco F, Pescarmona E, et al. A specific monoclonal antibody (PG-B6) detects expression of the BCL-6 protein in germinal center B cells. Am J Pathol. 1995;147:405-11.

25. Leong CW, Ottino JM. Increase in regularity by polymer addition during chaotic mixing in twodimensional flows. Phys Rev Lett. 1990; 64:874-7.

26. Cattoretti G, Pileri S, Parravicini C, Becker MH, Poggi S, Bifulco C, Key G, D’Amato L, Sabattini E, Feudale E, et al. Antigen unmasking on formalinfixed, paraffin-embedded tissue sections. J Pathol. 1993;171:83-98.

27. Shi SR, Key ME, Kalra KL. Antigen retrieval in formalin-fixed, paraffin-embedded tissues: an enhancement method for immunohistochemical staining based on microwave oven heating of tissue sections. J Histochem Cytochem. 
1991;39:741-8.

28. Marchese C, Chedid M, Dirsch OR, Csaky KG, Santanelli F, Latini C, LaRochelle WJ, Torrisi MR, Aaronson SA. . Modulation of keratinocyte growth factor and its receptor in reepithelializing human skin. J Exp Med. 1995;182:1369-76.

29. Frank S, Stallmeyer B, Kampfer H, Kolb N, Pfeilschifter J. Leptin enhances wound reepithelialization and constitutes a direct function of leptin in skin repair. J Clin Invest. 2000 Aug;106(4):501-9.

30. Repertinger SK, Campagnaro E, Fuhrman J, ElAbaseri T, Yuspa SH, Hansen LA. EGFR enhances early healing after cutaneous incisional wounding. J Invest Dermatol. 2004 Nov;123(5):982-9.

31. Galiano RD, Tepper OM, Pelo CR, Bhatt KA, Callaghan M, Bastidas N, Bunting S, Steinmetz HG, Gurtner GC. Topical vascular endothelial growth factor accelerates diabetic wound healing through increased angiogenesis and by mobilizing and recruiting bone marrow-derived cells. Am J Pathol. 2004 Jun;164(6):1935-47.
32. Frank S, Stallmeyer B, Kampfer H, Kolb N, Pfeilschifter J. Leptin enhances wound reepithelialization and constitutes a direct function of leptin in skin repair. J Clin Invest. 2000 Aug;106(4):501-9.

33. Kino Y, Kato M, Ikehara Y, Asanuma Y, Akashi K, Kawai S. Plasma leptin levels in patients with burn injury: a preliminary report. Burns. 2003 Aug;29(5):449-53.

34. Cakir B, Cevik H, Contuk G, Ercan F, EksiogluDemiralp E, Yegen BC. Leptin ameliorates burninduced multiple organ damage and modulates postburn immune response in rats. Regul Pept. 2005 Feb 15;125(1-3):135-44.

\section{Correspondence:}

Dimitris P. Korkolis

22 Socratous Street, $1^{\text {st }}$ Floor,

Kifissia 14561 Athens Greece

dkorkolis 2000@yahoo.com
Conflict of interest: none Financial source: none

Received: September 25, 2007

Review: November 21, 2007

Accepted: December 18, 2007

\section{How to cite this article}

Liapaki I, Anagnostoulis S, Karayiannakis A, Korkolis D, Labropoulou M, Matarasso A, Simopoulos C. Burn wound angiogenesis is increased by exogenously administered recombinant leptin in rats. Acta Cir Bras. [serial on the Internet] 2008 Mar-Apr;23(2). Available from URL: http://www.scielo.br/acb 